$$
\text { Conf-950454--7 }
$$

UCRL-JC-118652

PREPRINT

\title{
REACTIVE SPUTTER DEPOSITION OF YTTRIA-STABILIZED ZIRCONIA
}

\author{
A. F. Jankowski and J. P. Hayes
}

This paper was prepared for submittal to

International Conference on Metallurgical Coatings and Thin Films

in San Diego, CA, on April 24-28, 1995.

May 1995

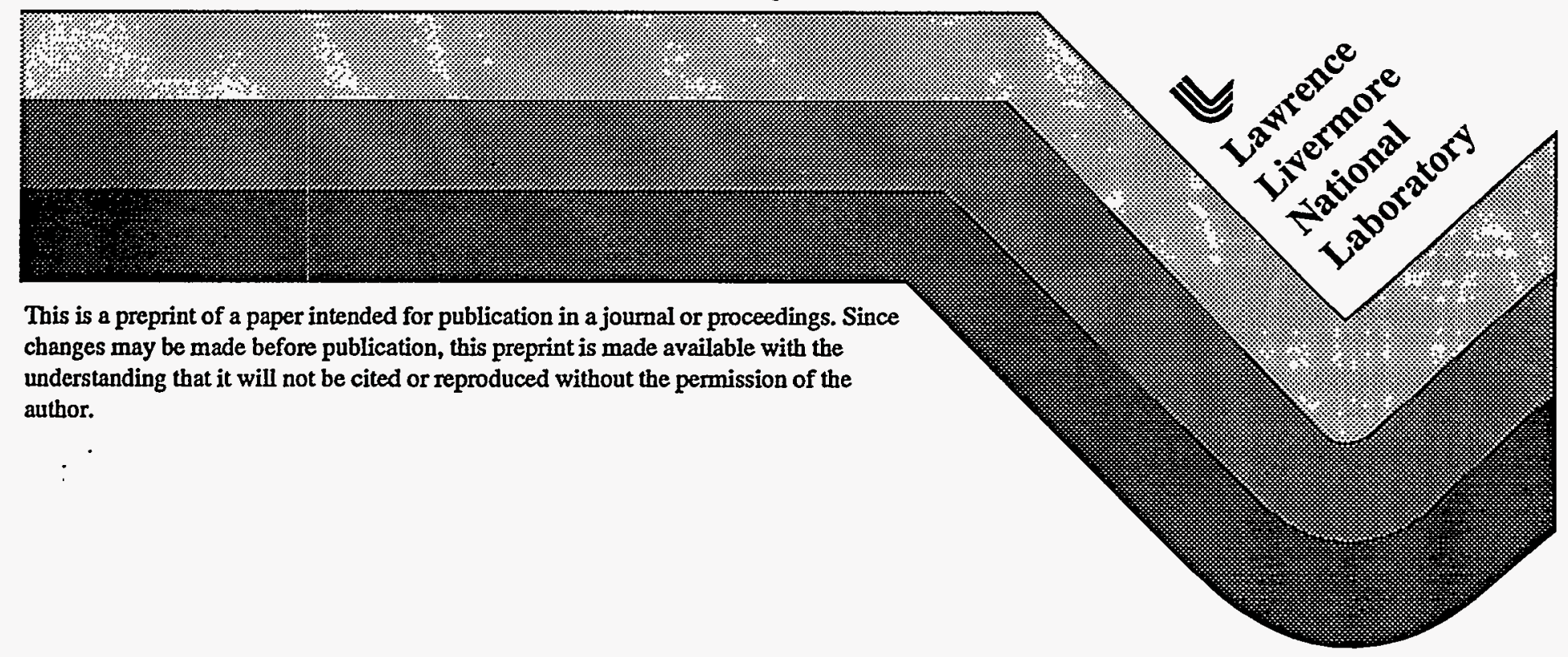




\section{DISCLAIMER}

This document was prepared as an account of work sponsored by an agency of the United States Government. Neither the United States Government nor the University of California nor any of their employees, makes any warranty, express or implied, or assumes any legal liability or responsibility for the accuracy, completeness, or usefulness of any information, apparatus, product, or process disclosed, or represents that its use would not infringe privately owned rights. Reference herein to any specific commercial product, process, or service by trade name, trademark, manufacturer, or otherwise, does not necessarily constitute or imply its endorsement, recommendation, or favoring by the United States Government or the University of California. The views and opinions of authors expressed herein do not necessarily state or reflect those of the United States Government or the University of California, and shall not be used for advertising or product endorsement purposes. 


\section{DISCLAIMER}

Portions of this document may be illegible in electronic image products. Images are produced from the best available original document. 


\title{
REACTIVE SPUTTER DEPOSITION OF YTTRIA-STABILIZED ZIRCONIA
}

\author{
A.F. Jankowski and J.P. Hayes \\ Lawrence Livermore National Laboratory, P.O. Box 808, Livermore, CA 94550 (U.S.A.)
}

Yttria-stabilized zirconia (YSZ) films are synthesized using reactive dc magnetron sputter deposition. A homogeneous alloy of $\mathrm{Zr}-\mathrm{Y}$ is synthesized and processed into a planar magnetron target which is reactively sputtered with an Argon-Oxygen gas mixture to form $\mathrm{Zr}-\mathrm{Y}-\mathrm{O}$ films. The sputtering conditions of gas flow, gas pressure, deposition rate and substrate temperature are determined in order to produce the cubic phase of zirconia as verified with $\mathrm{x}$-ray diffraction. A higher rate of deposition is acheivable when the sputtering mode of the $\mathrm{Zr}-\mathrm{Y}$ alloy target is metallic as opposed to oxide. The $\mathrm{Zr}-\mathrm{Y}$ composition of the planar magnetron target is designed for optimium oxygen-ion conductivity in the YSZ films, at elevated temperature for potential use in solid-oxide fuel cells. The oxygen concentration of the as-deposited films is measured using Auger electron spectroscopy and found to prinicipally vary as a function of the sputter deposition rate. A fuel cell is produced with the reactive deposition process using Pt electrodes from which the growth morphology of the YSZ layer is characterized using scanning electron microscopy. 


\section{INTRODUCTION}

The development of vapor deposition processes for synthesizing metal oxide films have found a wide variety of applications. Examples include use of oxide films as thermal barriers or for corrosion resistance. More recently, metal oxide films have been studied for potential use in solid oxide fuel cells (SOFCs) as thin electrolyte layers. Fuel cells based on oxygen-ion conductors, as stabilized zirconia, have been developed in recent years for electric power generation and considered as future alternatives for vehicle power supplies. ${ }^{[1-4]}$ In general, SOFCs consist of manifolded stacks of fuel cells enabling the combination of a fuel and oxidant at elevated temperatures to produce electrical current. The basis of each cell is an anode and cathode separated by an electrolyte layer. If the electrolyte can be made thinner, e.g. 1-2 $\mu \mathrm{m}$ thick as opposed to $10-20 \mu \mathrm{m}$, then the operating temperature for the SOFC can be reduced by several hundred degrees. ${ }^{[5]}$ If the composition can be optimized, as for the ion conducting electrolyte yttria stabilized zirconia (YSZ), then the efficiency of the cell is improved as well.[1.6] Thin YSZ films have been routinely formed using rf sputter deposition from electrically insulating oxidetargets that have a nominal composition of 5-6\% yttria. ${ }^{[7-9]}$

Our interest is to optimize the performance of YSZ electrolyte layer in application as an oxygen ion conductor at elevated temperatures $\left(500-700^{\circ} \mathrm{C}\right)$ by increasing the nominal yttria composition to $8 \%$. Tailoring the composition of the YSZ has been attempted using composite yttrium - zirconium metal targets. ${ }^{[10]}$ The homogeneity of the subsequent deposit is not insured, however, as a target composed of a mosaic of elemental pieces can produce compositionally rich regions in the deposit which pattern the sputtering target mosaic. In principle, the attempt to produce compositionally uniform films with an optimum yttria concentration is through the use of a metal alloy target as reactively sputtered in the dc mode. This unique approach offers the advantage of higher deposition rates and the higher oxygen conductivity found in a YSZ electrolyte layer as-deposited from a Zr-Y metal alloy target rather than conventionally acheived using a 5-6\% yttria target processed with if sputter deposition. The reaction rate of a metallic target with oxygen is effected by low gas pressure and flow conditions. ${ }^{[11-17]}$ Metal-oxide films as yttria can be 
formed, using reactive sputter deposition, with a range of compositions and structure previously unreported. ${ }^{[18,19]}$ Our synthesis approach emphasizes a deposition rate versuss film concentration relationship. [18-21] In this paper, we will focus on the method of target synthesis and the deposition parameters used to produce the YSZ films in configurations suitable for testing as electrolyte layers. Characterization of the film morphology will be accomplished through use of scanning electron microscopy. The film composition will be determined using Auger electron spectroscopy and the film crystal structure analized using $x$-ray diffraction. Eventually the YSZ films will be sputter deposited onto porous cermet substrates, i.e. the electrodes, to assess the process conditions needed to produce adherent, pinhole-free electrolyte layers for use in SOFCs.

\section{EXPERIMENTAL METHOD}

Yttria-stabilized zirconia (YSZ) films are synthesized using reactive dc magnetron sputter deposition. A homogeneous alloy of $\mathrm{Zr}-\mathrm{Y}$ is processed into a planar magnetron target by rolling an alloy button. The $\mathrm{Zr}-\mathrm{Y}$ button is first formed by electron beam arc melting $489 \mathrm{gms}$ of $\mathrm{Zr}$ and 86 gms of $Y$ to produce an alloy composition of 15 atomic percent $Y$. When appropiately oxidized, the resulting yttria-stabilized zirconia stoichiometry is $\left(\mathrm{Y}_{2} \mathrm{O}_{3}\right)_{0.08}\left(\mathrm{ZrO}_{2}\right)_{0.92}$. This $8 \%$ yttria composition yields the optimum oxygen ion conductivity for cubic YSZ at elevated temperatures.[6] The deposition chamber is cryogenically pumped from atmospheric pressure to a base pressure of $5.3 \times 10^{-6} \mathrm{~Pa}\left(4 \times 10^{-8} \mathrm{Torr}\right)$ in 12 hours which includes a $1.3 \times 10^{-5} \mathrm{~Pa}$ vacuum bake-out at $250^{\circ} \mathrm{C}$ for 2-4 hours. The $6.3 \mathrm{~cm}$ diameter $\mathrm{Zr}-\mathrm{Y}$ target is sputtered with an Argon-20\%Oxygen gas mixture to reactively form $0.5-3 \mu \mathrm{m}$ thick $\mathrm{Zr}-\mathrm{Y}-\mathrm{O}$ films. Substrates consist of $12.7 \mathrm{~mm} \times 12.7 \mathrm{~mm} \times$ $380 \mu \mathrm{m} \mathrm{Si}(111)$ wafers, $27 \mathrm{~mm} \times 46 \mathrm{~mm} \times 1 \mathrm{~mm}$ amorphous silica glass and $2.54 \mathrm{~cm} \mathrm{D} \times(11-13) \mu \mathrm{m}$ Pt foil. The substrates are horizontally positioned $8.9 \mathrm{~cm}$ away from the center of the sputter deposition target. The deposition parameters of current density, substrate temperature, working gas pressure and flow are determined in order to produce the cubic YSZ phase at high rate. High rate deposition is relative to process conditions where the target sputters in a metallic-mode as 
opposed to the low yield oxide-mode. At a target power (P) of 170 Watts and gas pressure (p) of $0.67 \mathrm{~Pa}$ (5 mTorr), a deposition rate hysteresis with gas flow $(\mathrm{q})$ is determined in order to define a specific flow for which both the oxide- and metallic- modes of target sputtering can be acheived. Selection of a specific flow will then allow for a near continuous variation of oxygen content in the forming film as a function of target power, i.e. current density which is proportional to the sputter deposition rate. The variation of oxygen composition in the deposited film as function of deposition rate has been shown for the reactive sputtering of Mo and Y metal targets. ${ }^{[18-21]}$ The initial hysteresis deposition experiment leads to the selection of a nominal gas flow with which to then conduct further deposition experiments to evaluate the dependency of oxygen content on deposition rate. The deposition rates are monitored with a $6 \mathrm{MHz}$ Au coated quartz crystal and confirmed using a thickness profilometer. The substrate temperature is controlled and varied by inductive heating to $700^{\circ} \mathrm{C}$, the operating temperature of a YSZ-based fucll cell. The cffect of substrate temperature on crystal structure is assessed in order to produce the desired cubic YSZ phase for use in fuel cell applications. For the purpose of eventually testing the electrolytic behavior of the reactive sputter deposited YSZ layer, depositions onto the Pt foil substrate are subsequently followed by a $0.5 \mu \mathrm{m}$ thick sputter deposition of a Pt top layer to create a unit cell. The Pt foil and top layer (which caps the YSZ layer) serve as the electrodes with well known behavior enabling assessment of the untested YSZ electrolyte layer. (Testing and analysis of the performance of this SOFC will be presented in a future publication.)

The $\mathrm{Zr}-\mathrm{Y}-\mathrm{O}$ samples are characterized using $\mathrm{x}$-ray diffraction (XRD), scanning electron microscopy (SEM) and Auger electron spectroscopy (AES). The crystal structure of each film deposited on the amorphous silica glass substrates is characterized in a powder diffractometer operated in the $\theta / 2 \theta$ mode. A graphite monochromator is used to provide $\mathrm{Cu} K \alpha$ radiation, at an $\mathrm{x}$-ray wavelength of $0.15406 \mathrm{~nm}$. The interplanar spacings (d) as measured via Bragg diffraction and corresponding Miller indices (hkl) are used for identification of the crystalline phase. Atomic concentration profiles of the films deposited on the $\mathrm{Si}(100)$ substrates are measured using AES coupled with depth profiling. A $3 \mathrm{keV}, 10 \mu \mathrm{A}$ electron beam is used to generate the Auger electrons. The measured intensities of Auger transitions for the $147 \mathrm{eV} \mathrm{MNN}$ zirconium peak and 
the $503 \mathrm{eV} \mathrm{KLL}$ oxygen peak (from data accumulated in the derivative mode) suffice to compute the oxygen atomic concentration. A $5 \mathrm{keV}, 2.2 \mu \mathrm{A}$ argon ion beam is used to sputter etch a 25 $\mathrm{mm}^{2}$ area of the sample surface. The gas pressure for the sputter etch is $4 \times 10^{-3} \mathrm{~Pa}\left(3 \times 10^{-5} \mathrm{Torr}\right)$ whereas the system base pressure is $6.7 \times 10^{-8} \mathrm{~Pa}\left(5 \times 10^{-10}\right.$ Torr). The Pt/YSZ/Pt SOFCs are prepared in cross-section for SEM imaging. Samples are cooled in liquid nitrogen and fracture cross-sectioned in order to examine the $\mathrm{Zr}-\mathrm{Y}-\mathrm{O}$ film continuity and growth structure. Secondary electron imaging as used to reveal the topology of the microstructure is coupled with back-scattered electron imaging to accentuate compositional differences bewteen the $\mathrm{Pt}$ and $\mathrm{Zr}-\mathrm{Y}-\mathrm{O}$ layers.

\section{RESULTS AND ANALYSIS}

\subsection{Deposition Conditions}

The sputter gas composition, pressure and flow each affect the stability of the sputtering process. ${ }^{111,12]}$ The sputtering mode of a reactive target in a partial oxygen pressure is sensitive to the oxidation kinetics. ${ }^{[13]}$ For example, when a sufficiently low oxygen pressure and flow exist, the target surface sputters as a metal.[15,16] A thorough examination of the sputter deposition parameters on the sputtering mode of the target and the formation of metal-rich oxides is given elsewhere. ${ }^{[18-21]}$ For this study, the gas composition and pressure are preselected whereas the flow is determined in order to change the sputtering mode of the $\mathrm{Zr}-\mathrm{Y}$ target by varying the applied target power. An increase in target power yields an increase in current density at the target surface. When the rate of removal of the surface yttrium-oxide exceeds the rate of oxide formation, the target surface will sputter as metal. This is evidenced by a sudden increase in the measured deposition rate (Fig. 1) as a result of (step 1) decreasing the gas flow from 10 to $4 \mathrm{cc} \mathrm{min}^{-1}$ (sccm) for a 5 mTorr gas pressure and an applied target power of 170 Watts. The $\mathrm{Zr}-\mathrm{Y}$ target continues to sputter in a metallic mode as (step 2) the gas flow is increased from 4 to $14 \mathrm{sccm}$. Upon reaching $15 \mathrm{sccm}$, the target becomes saturated with oxygen wherein the rate of removal does not exceed the rate of oxide formation, reverting the sputtering mode of the target to an oxide as indicated by the 
sudden decrease in depostion rate. The hysteresis is formed as (step 3) the decrease in flow from $15 \mathrm{sccm}$ will eventually lead to a metallic sputter mode. This initial deposition experiment (Fig. 1) leads to the selection of a nominal gas flow of $7 \mathrm{sccm}$ at $5 \mathrm{mTorr}$ (Fig. 1) with which to then conduct further experiments to evaluate the dependency of oxygen content on deposition rate.

The effect of current density on deposition rate is assessed through the synthesis of individual samples at incremented target powers which range from 75 to 450 Watts. The target current traces the change in target power. The effect of current on deposition rate (Fig.2) is proportional, continuous and almost linear (with a correlation coefficient of $0.969 \pm 0.001$ ). For this range of target powers, the $\mathrm{Zr}-\mathrm{Y}$ alloy target sputters as a metal as indicated by all of the deposition rates being greater than $0.1 \mathrm{~nm} \mathrm{~s}^{-1}$. The increase of substrate temperature to $700{ }^{\circ} \mathrm{C}$ does not effect the deposition rate for this material system. The $\mathrm{Zr}-\mathrm{Y}-\mathrm{O}$ coatings are adherent to the substrates surviving the common tape test. The visual appearance of the films change from a smoky brown $\rightarrow$ gray $\rightarrow$ specular silver as the deposition rate increases from $<0.3$ to $>0.5 \mathrm{~nm} \mathrm{~s}^{-1}$.

\subsection{Characterization}

The $\mathrm{Zr}$-Y-O films deposited on $\mathrm{Si}(111)$ wafers are compositionally depth profiled using Auger electron spectroscopy (AES). The variation of oxygen with target power, i.e. current density, is inverse to the change in deposition rate. Whereas an increase in target current leads to an increase in deposition rate, the oxygen content is found to decrease. This trend follows the kinetics of oxidizing the metal target. For constant pressure and flow, an increase in the number of metallic sputtered neutrals will lead to an increase in the metal content hence a decrease in the oxygen content. The film composition is found to be independent of substrate temperature. The desired concentration of a YSZ film composed of $8 \%$ yttria is nominally 65.8 at.\% oxygen. This oxygen content is found for films formed at $0.22-0.25 \mathrm{~nm} \mathrm{~s}^{-1}$ deposition rates. The selection of substrate temperature is then subject to films deposited at these rates in order to create the desired cubic YSZ phase.

The Zr-Y-O films deposited onto amorphous silica glass using deposition rates of $0.22-$ $0.26 \mathrm{~nm} \mathrm{~s}^{-1}$ (corresponding to target currents of 0.5-0.7 amps) are characterized using $\mathrm{x}$-ray 
diffraction (XRD). The examination of YSZ films using XRD is limited in this analysis to samples deposited at $700{ }^{\circ} \mathrm{C}$, the nominal temperature for which a SOFC would operate. Samples deposited at $0.22-0.23 \mathrm{~nm} \mathrm{~s}^{-1}$ (corresponding to the desired 65at.\% oxygen, i.e. 8\% yttria composition) with a $700 \pm 10^{\circ} \mathrm{C}$ substrate temperature yielded interplanar spacings and a computed lattice spacing of $0.514 \pm 0.0002 \mathrm{~nm}$ which indexed to the JCPDS-ICDD file no. 30-1468 for cubic $\mathrm{Y}_{.15} \mathrm{Zr}_{.85} \mathrm{O}_{1.93}$ with a lattice parameter of $0.5139 \mathrm{~nm}$. For samples synthesized at higher deposition rates which correspond to substoichiometric oxygen contents, the XRD patterns evidence the presence of several zirconia phases. For example, the XRD scan yielded interplanar spacings (see Table 1) of a $\mathrm{Zr}-\mathrm{Y}-\mathrm{O}$ film deposited at a $0.268 \mathrm{~nm} \mathrm{~s}^{-1}$ rate and $700 \pm 10^{\circ} \mathrm{C}$ substrate temperature (corresponding to a measured 50 at.\% oxygen film content) which can best be fitted to an orthorhombic phase having a (11) textured growth with calculated lattice parameters $\mathrm{a}=$ $0.3505, b=0.5646$ and $c=0.5275 \mathrm{~nm}$, similar to that of JCPDS-ICDD file no. $41-17$ for $\mathrm{ZrO}_{2}$. An unaccounted reflection with a $0.1859 \mathrm{~nm}$ interplanar spacing can be matched to the cubic YSZ phase, noting that all other cubic spacings superpose with the orthorhombic spacings. After subjecting this as-deposited film to a 2 hour $-200^{\circ} \mathrm{C}$ anneal in air to increase the oxygen content, the (111) textured film transformed to a mixture of equilibrium phases, i.e. cubic YSZ and monoclinic $\mathrm{ZrO}_{2}$ (as indexed to JCPDS-ICDD file no. 7-1484). The deposition rate clearly has an effect on stabilizing the cubic YSZ phase in the as-deposited (and air-annealed) Zr-Y-O film.

The fractured cross-sectioned Pt/YSZ/Pt cells all have a common structure as examined using scanning electron microscopy (SEM). A typical dense columnar growth is found, as for the $2.8 \mu \mathrm{m}$ thick YSZ layer (Fig. 3) processed with a $0.39 \mathrm{~nm} \mathrm{~s}^{-1}$ deposition rate (0.84 amp target current) at a $640^{\circ} \mathrm{C}$ substrate temperature. The YSZ layer appears continuous, i.e. there is no evidence of voids in this structure. 


\section{DISCUSSION \& SUMMARY}

A dc sputter deposition process has been developed to synthesize yttria-stabilized zirconia (YSZ) films from a $\mathrm{Zr}-\mathrm{Y}$ alloy target. Reactive sputter deposition in the dc mode offers the potential to acheive higher deposition rates than from oxide targets using rf sputter deposition. The proper deposition conditions are required to stabilize the cubic YSZ phase as a thin film growth. The reactive gas pressure and flow effect the kinetics of oxygen incoporation into the growing film as influenced by deposition ratc. In this study, with consideration to the application of the YSZ layer in a solid oxide fuel cell (SOFC), a $700^{\circ} \mathrm{C}$ substrate temperature is used to stabilize the growth of cubic YSZ when deposited at $0.22-23 \mathrm{~nm} \mathrm{~s}^{-1}$ using a $5 \mathrm{mTorr}$ pressure and $7 \mathrm{sccm}$ flow of an $\mathrm{Ar}-20 \% \mathrm{O}_{2}$ working gas mixture. The $\mathrm{Zr}-\mathrm{Y}$ alloy target composition is designed to potentially maximize the ion conductivity of the deposited YSZ as a electrolyte layer in a SOFC. The use of a thin dc sputtered YSZ film in a SOFC is shown feasible through synthesis of PUYYSZ/Pt cells which will be tested to evaluate the performance of the electrolyte layer.

\section{ACKNOWLEDGMENTS}

We thank $\mathrm{H}$. Olson for providing the SEM cross-section image. This work was performed under the auspices of the United States Department of Energy by Lawrence Livermore National Laboratory under contract W-7405-Eng-48. 


\section{REFERENCES}

1 N.Q. Minh, J. Am. Ceram. Soc., 76 (3) (1993) 563.

2 J.T. Brown, Energy, 11 (1990) 209.

3 A.J. Appleby, Int. J. Hydrogen Energy, 19 (2) (1994) 175.

4 R.H. Williams, Technol. Rev., 97 (3) (1994) 20.

5 S.A. Barnett, Energy, 15 (1990) 1.

6 J.F. Baumard and P. Abelhard, in A. Heuer and L. Hobbs (eds.), Advances in Ceramics, Vol. 3 Science and Technology of Zirconia II, Amer. Cer. Soc., Columbus, 1981, p. 555.

7 R.M. Goldstein and S.C. Wigginton, Thin Solid Films, 3 (1969) R41.

8 L.S. Wang and S.A. Barnett, Sol. Stat. Ionics, 61 (1993) 273.

9 A.F. Jankowski and J.P. Hayes, Univ. Calif., LLNL, Livermore, UCRL-JC-117501 (1994).

10 E.S. Thiele, L.S. Wang, T.O. Mason, and S.A. Barnett, J. Vac. Sci. Technol. A, 9 (6) (1991) 3054.

11 S. Berg, H.-O. Blom, T. Larsson and C. Nender, J. Vac. Sci. Technol. A, 5 (1987) 202.

12 S. Berg, H.-O. Blom, M. Moradi, C. Nender and T. Larsson, J. Vac. Sci. Technol. A, 7 (1989) 1225.

13 S. Maniv and W.D. Westwood, J. Appl. Phys., 51 (1980) 718.

14 A. Kinbara, E. Kusano and S. Baba, J. Vac. Sci. Technol. A, 10 (1992) 1483.

15 E. Hollands and D.S. Campbell, J. Mater. Sci., 3 (1968) 544.

16 T. Abe and T. Yamashina, Thin Solid Films, 30 (1975) 19.

17 F. Shinoki and A. Itoh, J. Appl. Phys., 46 (1975) 3381.

18 A.F. Jankowski, L.R. Schrawyer and J.P. Hayes, J. Vac. Sci. Technol. A, II (1993) 1548.

19 A.F. Jankowski, M.P. Stratman, E.M. Sedillo, J.P. Hayes and G.P. Gallegos, Surf. Coatings Technol., 61 (1993) 14.

20 A.F. Jankowski and L.R. Schrawyer, Thins Solid Films, 193/194 (1990) 61.

21 A.F. Jankowski and L.R. Schrawyer, Surf. Coat. Technol., 54/55 (1992) 349. 
Table I. Lattice (a,b,c) and Interplanar (d) Spacings (nm) of a Y-Zr-O film and Equilibrium Phases (JCPDS-ICDD file no.) with Peak Intensities (I) and Bragg Reflection (hkl) Identification

\begin{tabular}{ccccc}
\hline $\mathrm{Zr}-\mathrm{Y}-\mathrm{O}$ & $\mathrm{Zr}-\mathrm{Y}-\mathrm{O}$ & $\mathrm{Y}_{.15} \mathrm{Zr}_{.85} \mathrm{O}_{1.93}$ & $\mathrm{ZrO}_{2}$ & $\mathrm{ZrO}_{2}$ \\
as-deposited & annealed & $30-1468$ & $41-17$ & $7-1484$ \\
orthorhombic & monoclinic +cubic & cubic & orthorhombic & monoclinic \\
$\mathrm{a}=0.3505$ & & 0.5139 & 0.3327 & 0.5313 \\
$\mathrm{~b}=0.5646$ & & - & 0.5566 & 0.5213 \\
$\mathrm{c}=0.5275$ & & - & 0.6487 & 0.5147
\end{tabular}

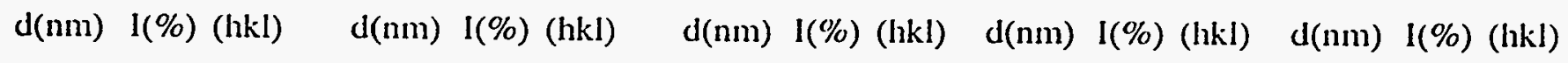

\begin{tabular}{|c|c|c|c|c|c|c|c|c|c|c|c|c|c|c|}
\hline & & & 0.3684 & 10 & 110 & & & & & & & 0.3698 & 14 & 110 \\
\hline & & & 0.3162 & 100 & -111 & & & & & & & 0.3165 & 100 & -111 \\
\hline 0.2919 & 11 & 101 & 0.2965 & 23 & 111 & 0.2968 & 100 & 111 & 0.294 & 100 & 101 & & & \\
\hline 0.2823 & 15 & 020 & 0.2847 & 26 & 111 & & & & 0.278 & 100 & 020 & 0.2841 & 68 & 111 \\
\hline 0.2622 & 100 & 111 & 0.2626 & 22 & 200 & & & & 0.262 & 75 & 111 & 0.2623 & 21 & 200 \\
\hline \multirow[t]{2}{*}{0.2489} & 76 & 021 & 0.2538 & 11 & 002 & 0.2571 & 25 & 200 & 0.255 & 50 & 021 & 0.2540 & 13 & 002 \\
\hline & & & 0.2211 & 13 & -112 & & & & & & & 0.2214 & 12 & -112 \\
\hline \multirow[t]{2}{*}{0.1921} & 9 & 022 & 0.1996 & 15 & -202 & & & & 0.202 & 50 & 121 & 0.1991 & 6 & -202 \\
\hline & & & 0.1845 & 16 & 220 & & & & & & & 0.1848 & 18 & 220 \\
\hline 0.1859 & 3 & 220 & 0.1810 & 27 & 022 & 0.1818 & 55 & 220 & 0.180 & 50 & 103 & 0.1819 & 22 & 022 \\
\hline \multirow[t]{2}{*}{0.1631} & 5 & 211 & 0.1658 & 14 & 310 & & & & 0.166 & 20 & 200 & 0.1657 & 11 & 310 \\
\hline & & & 0.1588 & 4 & -131 & & & & & & & 0.1592 & 4 & -131 \\
\hline 0.1518 & 6 & 032 & 0.1541 & 14 & -203 & 0.1550 & 40 & 311 & 0.154 & 50 & 211 & 0.1539 & 7 & -203 \\
\hline 0.1484 & 7 & 220 & 0.1500 & 15 & -312 & 0.1484 & 6 & 222 & 0.143 & 20 & 220 & 0.1496 & 5 & -312 \\
\hline 0.1383 & 12 & 040 & & & & & & & 0.139 & 10 & 040 & & & \\
\hline & & & 0.1326 & 12 & -223 & & & & & & & 0.1325 & 2 & -223 \\
\hline
\end{tabular}


Figure Captions

1 The deposition rate $\left(\mathrm{nm} \mathrm{s}^{-1}\right)$ variation with gas flow $\left(\mathrm{cc} \mathrm{min}^{-1}\right)$ for a reactively sputtered $\mathrm{Zr}-\mathrm{Y}$ alloy target using an $\mathrm{Ar}-20 \% \mathrm{O}_{2}$ gas mixture at constant target power $(170 \mathrm{~W}$ ) and gas pressure (5 mTorr). A hysteresis with deposition rate is formed when the gas flow is changed in the direction shown from step (1) through step (3).

2 The oxygen concentration (at.\%) and target current (amps) variation with deposition rate for a reactively sputtered $\mathrm{Zr}-\mathrm{Y}$ alloy target using an $\mathrm{Ar}-20 \% \mathrm{O}_{2}$ gas mixture at constant gas pressure (5 mTorr) and flow $\left(7 \mathrm{cc} \mathrm{min}^{-1}\right)$.

3 The scanning electron microscope image of a fracture cross-sectioned Pt/YSZ/Pt cell structure. The YSZ layer (middle) is first sputter deposited onto the Pt foil substrate (bottom) and then a Pt layer (top) is sputter deposited to complete the cell. 


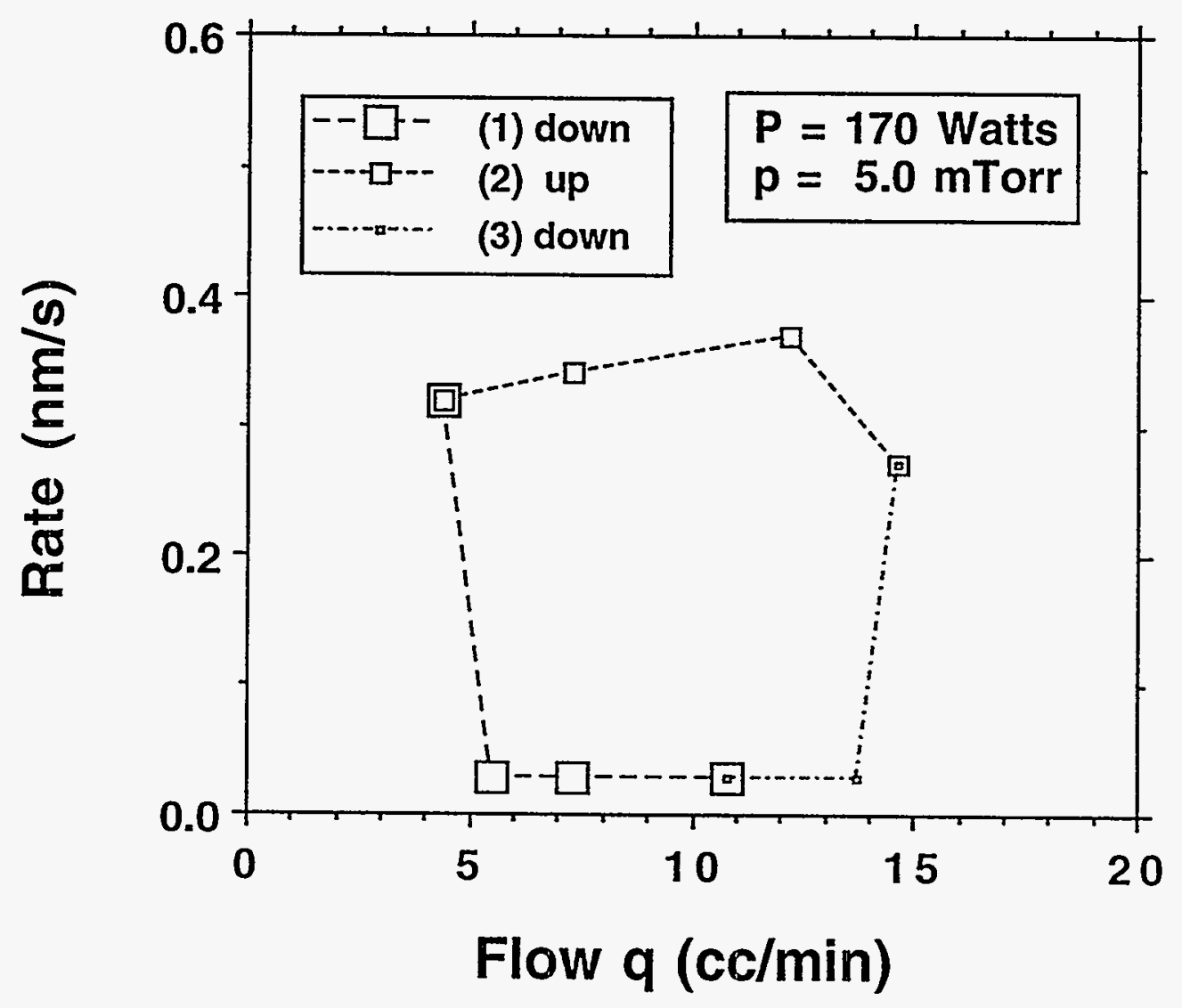

Figure 1. 


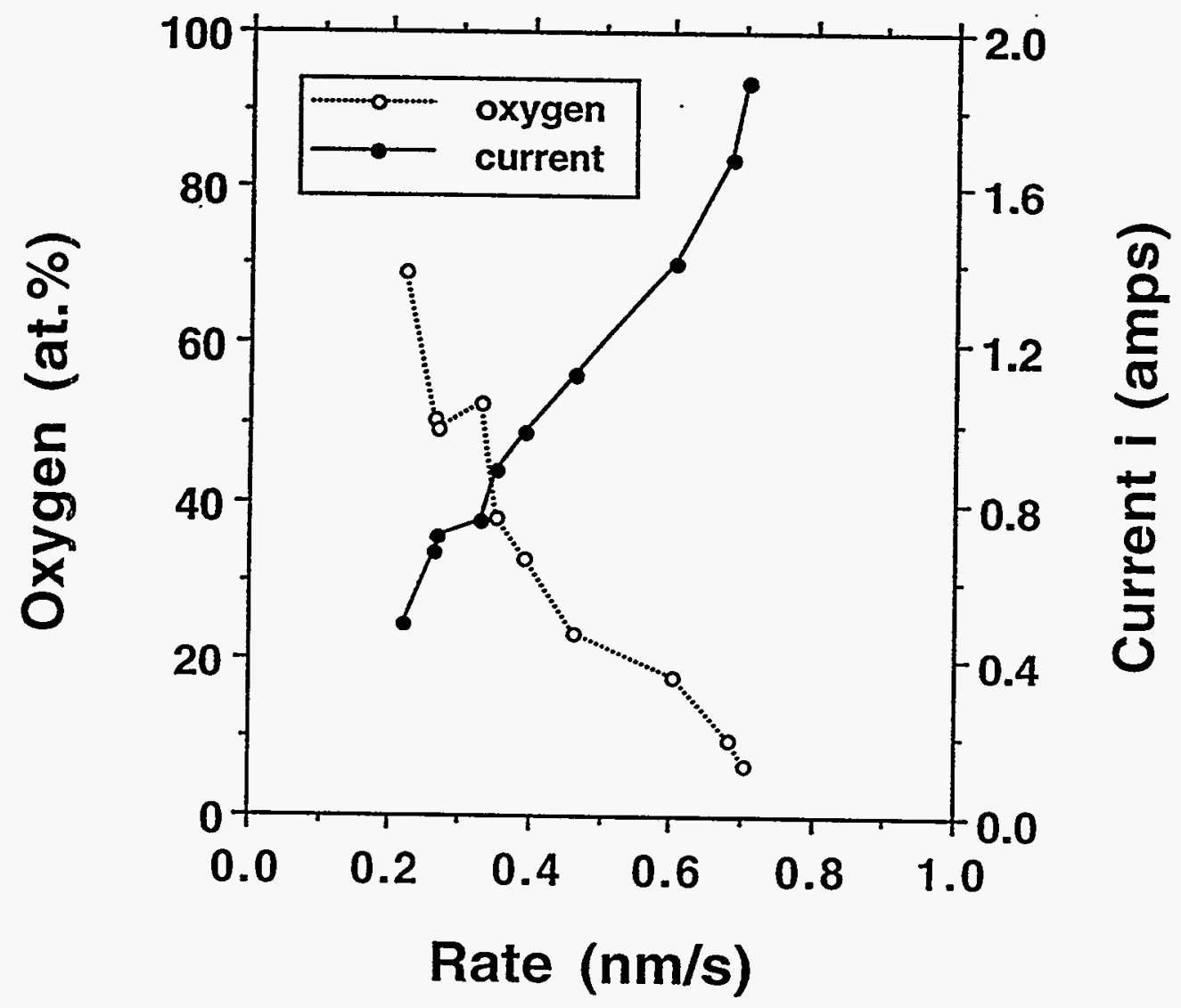

Figure 2. 


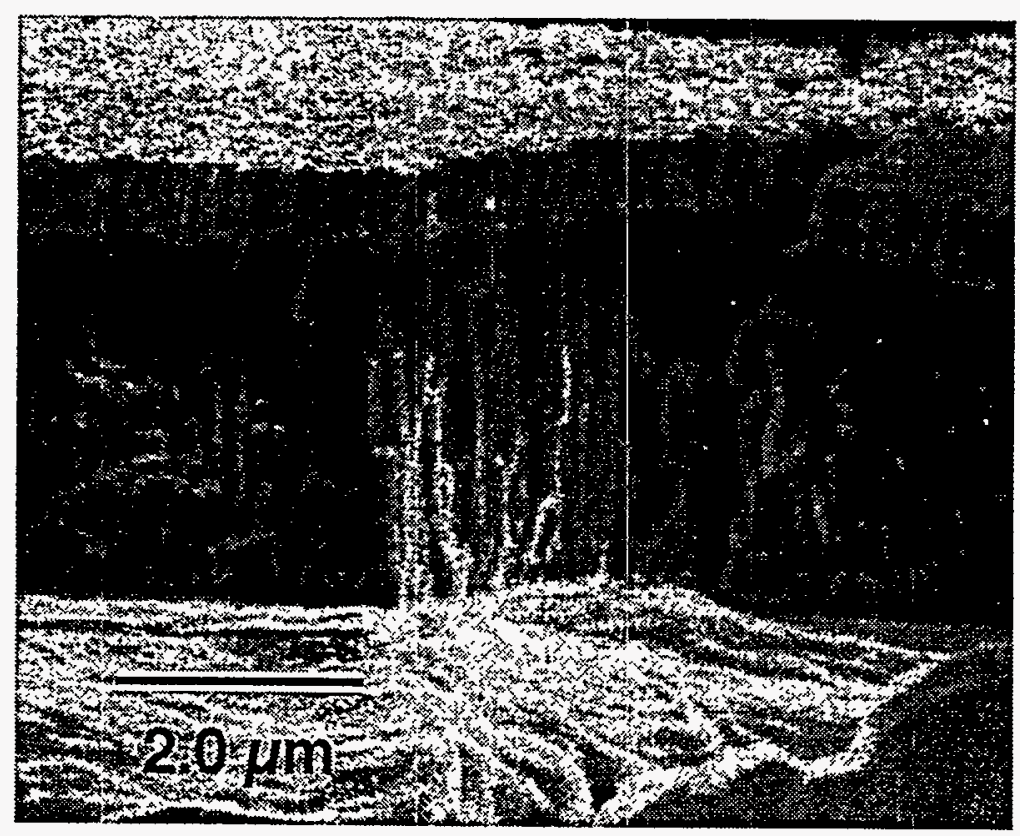

Figure 3. 